\title{
CORRECTION
}

View Article Online

View Journal I View Issue

Check for updates

Cite this: RSC Adv., 2021, 11, 30925

DOI: 10.1039/d1ra90143e

rsc.li/rsc-advances

\section{Correction: Pickering-emulsion-templated} synthesis of 3D hollow graphene as an efficient oil absorbent

\author{
Nurul Aqilah Pohan, (D) a Mohd Haniff Wahid, (D) *a Zulkarnain Zainal (D) ab \\ and Nor Azowa Ibrahim iD a \\ Correction for 'Pickering-emulsion-templated synthesis of 3D hollow graphene as an efficient oil \\ absorbent' by Nurul Aqilah Pohan et al., RSC Adv., 2021, 11, 3963-3971. DOI: 10.1039/D0RA09265G.
}

The author regrets that the funding information was incorrectly shown in the Acknowledgements section of the original manuscript. The corrected funding acknowledgements are as shown below.

The authors would like to thank the Ministry of Education of Malaysia for funding this study through grant no: FRGS/1/2018/ STG01/UPM/02/11. Special thanks are extended to NanoMalaysia Berhad and Tex Cycle Technology (M) Berhad. Nurul Aqilah Pohan would like to thank the Ministry of Education of Malaysia for the Special Graduate Research Allowance Scheme.

The Royal Society of Chemistry apologises for these errors and any consequent inconvenience to authors and readers. 